\title{
Globalization and Christian Values in Nigeria
}

\author{
Friday Ifeanyi Ogbuehi \\ Crowther Graduate Theological Seminary, Abeokuta, Ogun State, Nigeria
}

\begin{abstract}
Globalization is the interconnectivity and interdependence of nations on one another which has reduced the world into a global village. Previous writers have grossly neglected the influence of globalization on Christianity, partly due to the limitation of globalization to capitalism and international relations. Nevertheless, it has been discovered that the church is missionary, ecumenical, evangelical and universal (Catholic) which has exposed the church to the influence of globalization. Therefore, the paper will compare the positive and negative impact of globalization on Christian values which will help to address the inconsistencies of globalization on Christian values. The study used comparative method. It was descriptive and analytical. The writer used primary and secondary sources. Globalization is not a new development in global interaction, interconnectivity and interdependence occasioned by easy movement of humans, goods and services across the borders and development in Information and Communication Technology. Christianity has indirectly been in the vanguard of globalization. Globalization as a social phenomenon has been instrumental to the spread of the gospel across the globe. It has aided relationships between churches in the country and other churches outside the shores of the country and international bodies. However, globalization has helped to spread false doctrine and values which contradict Christian values. It has caused unhealthy rivalry among churches in the world. Globalization has robbed some countries of their autonomy which has caused people to view globalization as another form of colonialism (neo-colonialism). The paper recommended that the church should remain resilient in upholding sound Christian values against adulteration and revisionism.
\end{abstract}

Keywords: Globalization, Values and Christianity and Nigeria.

DOI: $10.7176 / \mathrm{JAAS} / 73-01$

Publication date:June $30^{\text {th }} 2021$

\section{Introduction}

It is said that no man is an Island. Naturally, human beings are social animals that interact with one another. There is no doubt that the more people or institutions interact with one another the more they influence the values of one another. Christianity came to Nigeria before the creation of Nigeria by Lord Luggard in 1914. This implies that apart from Islam that came earlier before Christianity, Christianity is a second religion that paved way for massive contacts with colonialism and European Missionaries that influenced every sector of the national life. This external and imperial influence no doubt brought blessings and woes on the country. Modern Christianity is grappling with many challenges of which one of them is globalization. It has been discovered that Christianity is threatened by so many values that are in conflict with Christian values. Some Christians are imbibing these values without minding the dire consequences on their Christian faith. It should be noted that science, International trade, International relations, International conferences, foreign education, foreign religions (Christianity and Islam), foreign Missions, Information and Communication Technology (ICT) and even human beings are some of the agents of globalization. Scientific values of verification, objectivity, scientific theories have rendered Christian values meaningless. There is re-orientation on human sexuality, biblical truth, miracle, existence of God, power of God, prayer, heaven, death and resurrection of Christ, coming of our Lord Jesus Christ, morality, virgin birth, Trinity, faith, infant baptism and salvation. These are some of the core Christian tenets that are under fire. If these Christian values are pulled down, there is nothing left that will sustain Christianity. Therefore, it has become expedient to explore the influence of globalization on Christian values with the aim of rescuing Christian values from total extinction.

\section{Conceptualization of Terms}

Globalization

Globalization is a universal phenomenon. Ozumba (2018) states that globalization was derived from the adjective, global, which means worldwide coverage. It means the interconnectivity and networking of all nations which embrace their economies, politics and socio- religious, scientific and technological developments. According to Uzukwu (1996) globalization is link between nations in which the link enhances relationships and obligations of nations to one another. Dike (2015) sees globalization from capitalist view when he asserts that globalization is "the trans-nationalization of capital and the standardization and homogenization of consumer tastes". Globalization is not limited to capitalism; it covers every aspect of life. Gwamna (2010) intones that globalization is the network of world-wide communication systems known as cybernetic devices which are used in reducing the world into a global village. It is facilitated by electronic mail (e-mail), faxes, internet, cellular 
mobile phones, the World Wide Web (www). Diara (2010) says that globalization is a product of capitalism which was brought about by Christianity in Britain in the $17^{\text {th }}$ century. It is the architect of cultural and social change.

\section{Values}

Ofoego (2017) describes values from the educational perspective when she asserted that "values connote importance, something that is qualitatively cherished, something that provides admiration, satisfaction and a sense of accomplishment". Values are those things that have innate qualities that attract importance and admiration. Igboabuchi and Ofojebe (2010) state that the term 'value' was formally an economic term used to describe the worth of a thing. It connoted the amount or prices of commodities during exchange of goods. Later, values were employed to mean rightness, virtue, obligation, truth, holiness and beauty. Values are used more in ethics and aesthetics to offer explanation of the beauty of good moral conduct. Okoli (2012) avers that values are "beliefs a person or group of people hold so dear, appreciate, esteem, reward and have a deep emotional investment". Values are convictions held by a person or a group of people. Agha (2003) observes that value is a quality found in an object either animate or inanimate object that inspires people's admiration. Okaneme (2010) quips that values are "principles, standards or qualities worthwhile or desirable". Christian values are beliefs and practices that are important for Christians. Osaghae and Haaga (2017) maintain that in Christianity there is no distinction between morality and value. For Christians value is anything that can provide a satisfactory solution to a problem.

\section{Christianity}

Cross and Livingstone (1974) are of the view that the name Christian from which Christianity was derived was formally used to describe followers of Christ by outsiders. It was first used at Antioch in c.AD.40-44 (Acts 11 ;26). The word Christian appears 2 times in New Testament, where Agrippa (King) used the name to address Paul (Acts 26:28). Peter used the name Christian to refer to those that are passing through persecution (1 Peter 4:16). The name Christian came into prominence in Neronian persecution (AD 64) which was used officially in addressing members of the church. Perhaps, the connection of the name Christian with Christ which was a messianic title led the people to conceive Christianity as a quasi-political movement. The early writers avoided the use of the term Christian and Christianity owing to its pagan origin. Christianity means a religion of followers of Christ. Richardson (1969) states that Christianity was originally used to designate the religion of the disciples, brethren, saints and people of the way. Christians are the adherents of Christianity. Christianity is an offshoot of Judaism. It is believed that Jesus Christ is the founder of Christianity. Christianity is a religion that was founded on the teachings of Jesus Christ. It is estimated that about 33\% of the population of the world are Christians (Watkins and Watkins, 1990). It is believed that Christianity is the largest world religion with about 2.4 billion followers. The tenets of Christianity are enshrined in the scriptures (Akah, 2016).

\section{Globalization in Nigeria}

Ozumba (2018) made it clear that globalization is not a new phenomenon. It dates back to the Egyptians, MedoPersians, Assyrian, Babylonians and Roman Empire that used conquests to dominate almost the world. Ugwuanyi and Agwu (2012) categorized globalization into three stages, archaic globalization, protoglobalization and modern globalization. The first stage of globalization is archaic globalization which took place in the Hellenistic age that witnessed the domination of commercialized urban centres, India to Spain, Alexandria, Athens and Antioch by Greek culture. Globalization occurred with the help of trade links between the Roman Empire, the Parthian empire and the Han Dynasty. It was also facilitated by Jewish and Muslim traders and explorers. The second phase is known as proto-globalization which was characterized by the rise of European Empires in the $16^{\text {th }}$ and $17^{\text {th }}$ centuries (Portuguese, Spanish and later Dutch and British Empires). Modern globalization was occasioned by the industrialization of the $19^{\text {th }}$ century with its attendant production of goods and services. It saw to the worldwide expansion of multinational corporations based in United States and Europe. This has been sustained by an increase in science and technology.

The country experienced globalization for the first time when Muslim traders from North Africa came to Northern Nigeria for economic transactions. They spread Islamic faith and transacted their businesses concurrently. It was followed by the British colonial administration that carried out expeditions in some parts of this country. They used military force to subject the natives to British hegemony, thereby destroying indigenous culture and replacing it with European culture. The British expeditions were, Aro Expeditions (1901-1902), the Ezza Patrol (1905), the Ahiara Expedition (1906), the Ontisha Hinterland Campaign and the Niger-cross River Expedition (1908) (Nwala, 1985). It should be noted that since the amalgamation of the country in 1914 by Lord Luggard, this country has belonged to International organizations which indicates its connection with globalization.

The country endorsed globalization by belonging to global organizations. It is a member of organization of 
Islamic Countries (OIC), United Nations (UN), Economic Communities of West Africa Sates (ECOWAS), African Union (AU). Uchechukwu et al (2018) posit that the International Communities through diplomacy fight for the rule of law in member countries. The United Nations (UN), Economic Communities of West Africa Sates (ECOWAS) and other international organizations sanction countries where political leaders involve in abuse of human rights, autocratic government, production of nuclear weapons of mass destruction and dictatorship. Globalization of politics has occasioned a situation where international organizations interfere with political anomalies that happen in other countries, particularly, member countries. Every member of United Nations, (UN) is expected to protect human rights as enshrined in the United Nations Declaration of human rights.

Uzukwu (1996) declares that globalization destroys "nation-prison". It creates an awareness that nations' rights and privileges are interconnected with rights and privileges of all children, youths, women and men of other nations. Globalization has made human rights interrelated, interdependent and international. Okafor (2004) submits that globalization is an act of removing barriers among nations with the aim of making the world a global village. It enhances interaction among the nations in the areas of free movement of goods, raw materials and services (trade), common currencies, exchange of knowledge and technical knowhow, tourism and migration, movement of human capital or resources and access to health facilities. It has created a network of relationships among nations and is responsible for interconnectedness, interaction and interdependence among companies, non-governmental organizations (NGOs), governments and people. There are easy and smooth flow of people, ideas, artifacts and culture from one country to another. There are networks of communication and interaction among institutions like world Trade organization (WTO), the World Bank, the international monetary fund (IMF) and professional groups (Fraser, 2008).

Griffiths (2010) argues that globalization has made it possible for the G8 countries ( Italy, Germany, United Kingdom, United States, Russia, Canada, France and Japan) to plan for a way of helping sub-saharan Africa overcome their debt as well as aid and foster their trade. Achunike (2004) observes that globalization with its attendant making of the world a global village has increased the rate of freedom of expression, communication revolution (mass media, electronic media, television and internet). Globalization has created an enabling environment for democracy to thrive and flourish in developing countries. In this country, the former national chairman of Peoples Democratic Party (PDP), Solomon Lar said that globalization has paved way for the democratically elected government which began since 1999 (Alli, 2006).

Okere (2005) reveals that the country has incurred protracted debt from the International Monetary Fund (IMF) which has resulted in protracted indebtedness of the country and it uses the money meant for the welfare of the citizens to service the debt. The developed countries find it difficult to transfer technology to the developing countries. Despite the fact that this country is the giant of Africa, it has not been recognized by the United Nations (UN) as one of the world powers. This country has not been given a pride of place in the Security Council. Some foreign banks have colluded with corrupt political leaders to stash money looted from public funds in foreign banks. McGuire (1997) is of the view that globalization has led the developing countries to depend on developed countries for loans and imported technology. The third world countries of which Nigeria is one of them depend on developed countries for the sale of their raw materials. It is discovered that the developed countries have established their multinational companies in developing countries that yield less income to the host countries' coffers (under payment of taxes) and increase the high rate of risk on the environment of the host countries.

Chukwuemeka (2004) insists that neo- colonialism is a situation where the powerful nations make policies that govern the weak and under developed countries. Neo-colonialism is a brain child of colonialism. The country has witnessed social crimes more than ever before. There is an increase in the rate of human trafficking, sex tourism, illegal migration, prostitution, drug abuse, drug-trafficking, money laundry, criminals seeking asylums in foreign lands due to free movement of goods and services. According to Nma (2008), these social atrocities and crime are attributed to global sex trade and unquenchable desire by industrial nations to acquire cheap labour. Globalization has resulted in an increased spreading of radical Islamic and terrorist attacks in the continent. Sometime ago, US Embassies in Kenya and Tanzania were burnt down. It is believed that terrorists in Sudan and Libya have connections with the Al Quaeda. Islamic terrorists that were trained in terrorist's camps in Afghanistan, Libya and Sudan have caused attacks on some countries in the world. There is a relationship between Al Quaeda and Africa in areas of weapons' smuggling, money laundering and training of terrorists. Radical Muslims are determined to fight globalization of the west which is believed to be used by the west to impoverish the third world. This has led the radical Muslims to launch terrorist's attacks on the western countries (Mbah, 2007).

Ehusani (nd) discloses that the international bodies have not given adequate attention to the challenges that confront Africa in their quest for globalization. These challenges include malnutrition, low standard of living, lack of access to basic education, inaccessibility of healthcare, lack of access to basic education, lack of social services, spread of AIDS, International debt, arms and human trafficking, increased rate of refugees and displaced persons and high rate of migration to overseas. 


\section{Globalization and Christian Values}

Christianity is an agent of globalization. Obilo (1986) argues that the Anglican Church being Catholic is a universal church that still retains its episcopate, historic creeds and sacraments which are the hall marks of an undivided church. Also, Anglicana Ecclesia ( Anglican Church) believes in the communion of saints (communio santorum). It is based on this that Oparaojiaku (1997) stresses that the catholicity of the Anglican Church indicates that the church holds strictly to the universalism of the gospel. It implies that the gospel is not limited to a race, ethnic, tribal and national enclaves. Communion of saints which constitutes the doctrine of Anglican church as enshrined in the apostles' creed provides a platform where the living commune with the saints (church Militant and church Triumphant).

Stott (1963) sees a close relationship between mission in overseas and globalization when he affirms: perhaps God will call you into the ministry of the gospel or to go overseas as a missionary. There is no greater privilege this side of heaven than such service. The world is still waiting to be evangelized. Millions of people have never heard of Jesus Christ and His salvation.

In order words, there is no way the church can reach the unreached unless it aligns itself with globalization. Christianity as a whole is a universal religion, by being a world religion, it is indispensable to world history. Globalization is a vehicle for spreading the gospel to the world, history of nations and world are incomplete without Christianity. Christianity as one of the agents of globalization has contributed a lot to social progress, educational development, interpersonal and international cooperation among nations. Achunike (2004) states that Demos Shakarian who was a wealthy American Dairy farmer founded Full Gospel Businessmen Fellowship International (FGBFI) which has reached millions of Christians worldwide. It is a Christian fellowship that unites Christian business men and women together as a worldwide family. This fellowship is a global Christian organization that inculcates Christian business principles among the members of the fellowship. Griffiths (2010) quoted Pope Benedict XVI as saying “in today's complex situation, not least because of the growth of a globalized economy, the church's social doctrine has become a set of fundamental guidelines offering approaches that are valid even beyond the confines of the church". Casanova (2013) quipped that the Jesuits were the first Globalizers that evangelized the world. They connected the North and South, East and West. The Jesuits spread the culture of the East to Europe and Europe to the East. They were accompanied by colonizers, Portuguese and Spanish.

Adegbite (2016) submits that peace is one of the values of the kingdom that showcases the reign of Christ. The kingdom of God presupposes peace in human relationships. Christian view of the kingdom is the reign of Christ in the world. Tillich (1957) remarks that American religious and humanist maintained that the kingdom of God is realized if there are peace, justice and democracy. For them, the kingdom of God consists of peace, justice and democracy in the twenties. Christianity is a religion of values which its adherents are compelled to observe. Omoregbe (1993) opines that the kingdom values are higher values among other values. Some of these values are human life, justice, honesty, fidelity, human freedom and fundamental human rights. The church champions the protection of human dignity. Glendon, (ny.1) claims that the Roman Catholic Church is not a stranger to globalization. It is a church that places premium on mission with the aim of spreading the good news to every nook and cranny of the earth. By so doing, the church has spread Christian values of justice, freedom, respect for the dignity of the person, the common good and peace. The Roman Catholic Church with the help of globalization has made humanity to become a single family, thereby promoting values of justice, equity and solidarity.

For some people, Christian values transcend the secular and technological values by remaining resilient and flourish in the midst of injustice that overwhelms the global age. Christianity has not declined from its traditional role of propagating the gospel for the universal salvation of humankind (Cook, 1991). The church prepares people for the kingdom of God which influences every department of life. Theologians like Kant, Schleiermacher, Lepsins, Oosterzee and Maurice are of the view that the kingdom of God is central to church dogmatism and ethics. The kingdom of God influences Christian theology and ethics. It appears in the Old Testament and Apocrypha. Kingdom of God means ruler ship of God and divine administration in the universe. The kingdom of God is universal and cuts across all spheres of human life. It is worthy of note that the kingdom of God has influence on objects, persons, events, nations, operations, nature and history. The doctrine of the kingdom of heaven was derived from Daniel ii.44, vi. 26, vii.13, 14 and 27 (Carter, Weeks et al, 1933). The kingdom of God is characterized by Justice which is the mark of true and universal God who rules the history according to His purpose. God exercises his ruler ship over His creatures by making sure there are justice and fair play in the divine administration of the universe (Tillich, 1963).

Dillenberger (1961) quoted Martin Lurther as saying that there are two kingdoms, God's kingdom and temporal kingdom. He said that Children of Adam are into two kingdoms, the kingdom of God ruled by Christ and the kingdom of the world led by the state. The state prescribes law that governs the life and property and the kingdom of Christ makes law for the soul. Perhaps, Luther's view of the kingdom of God and the kingdom of the 
world created a dichotomy between the kingdom of God and the secular state. According to Ajaero (2018), in the first century, Christians were taught that there were two kingdoms, temporal authority (state) and the kingdom of God (higher authority). Christians were not forbidden from giving to Caesar what belonged to Caesar. In other words, they were instructed to pay taxes and observe the laws of the state. Pauline view of the relationship between the state and the kingdom of God has been that Christians should subject themselves to the authorities. It is only the wrong doers that are afraid of those in authority due to the authorities do not punish people in vain.

The missionaries played a pioneering role in formal education by establishing schools for learning how to read and write. They instilled into the people the consciousness for nationalism which led to Independence of the country in $1^{\text {st }}$ October, 1960. It was the Missionaries that fought obnoxious cultural practices like slave trade, killing of twins, burial of prominent personalities, especially Kings with human heads, trial by ordeal, witchcraft, cannibalism, human sacrifice, widowhood practice and gender discrimination. The Missionaries substituted these obnoxious cultural practices and values with Christian values of love, kindness, peace, equality, human dignity, respect for human life (thou shall not commit murder), chastity, generosity, mercy, forgiveness, tolerance, truthfulness, self control, hospitality and faithfulness.

\section{Negative Influence of Globalization on Christian Values}

The priestly prayer of Jesus that they may be one is aimed at fostering unity of the church (John 17:21). It is noteworthy that the churches responded to the ecumenical prayer of Jesus by founding the world council of churches (WCC) in Amsterdam in 1948. Today, the world council of churches has members from more than 100 countries with its headquarters in Geneva Switzerland (Iluno, 2015). The visions of the World Council of Churches are to seek for unity of the church by one baptism, one Apostolic Faith, one Gospel, one breaking of the bread and common prayer irrespective of differences in creed, ethnicity, tribe and nationality (Obilor, 2014:11). The church of Nigeria was influenced by the Lambeth conferences which had shaped the church. History has it that the first Lambeth conference was held in 1867 which was chaired by the Archbishop of Canterbury, Thomas Longley. The laity- arm of the Lambeth conference known as Anglican Consultative Council (ACC) was inaugurated on $31^{\text {st }}$ October, 1969 after one hundred years of Lambeth conference (Nwankiti, 2000).

The Pope of the Roman Catholic Church has influence over Roman Catholic Church Worldwide. This has caused the Roman Catholic Church in Nigeria not to be an independent church. The church depends on Rome in matters of doctrine, liturgy and administration (Ndiokwere, 1994). Globalization has created a forum for international conferences to be held across the globe. At these conferences of various denominations, Christians of various faith tend to influence one another. The resultant effects of international conferences of various denominations are heresies and Christian 'syncretism' (Wach, 1958).Similarly, the Anglican Church worldwide led by the Archbishop of Canterbury used to have influence on church of Nigeria, Anglican Communion before the latter severed its relationship with the former over the controversial issue of homosexualism. According to Ubani (2016), the church of Nigeria under the leadership of Jasper Akinola who was the primate of the Anglican church of Nigeria severed relationship with the Anglican Church Worldwide over the consecration of Gene Robinson who was consecrated Bishop of New Hampshire, United States on June 7, 2003. In the following year, United States, Mexico, Canada and South Africa followed suit by insisting on wedding and consecrating gays as bishops. This prompted the Anglican Bishops led by Peter Akinola to boycott the Lambeth conference held in June, 2008 by Archbishop Rowan Williams. The church of Nigeria and other provinces outside Church of Nigeria refused to attend Lambeth Conference, rather, they attended Global African Future Conference (GAFCON) in Jerusalem in the same 2008.

Nkwoka (nd) is of the view that the church is challenged by revisionist agenda in the international arena. The revisionists are committed to their ulterior motives of re-writing the Bible, interpreting God and miracles out of context. Of recent, the homosexuals and lesbians justify their sexual perversion by claiming that it is how God created them. They use their economic and political powers to lure the disadvantaged Anglican dioceses to accept their position and dance to their tunes. It is discovered that some Western Anglican Churches have changed the 1662 edition of common Book of Prayer. Ireoba (2018) asserts that due to the opposition of the African Bishops to the American revisionist dioceses, the latter have withdrawn their financial aids to the needy African dioceses. Ireoba quoted John Rucyahana, Bishop from Rwanda as saying "this has happened to many other African countries and African churches over opinion and independence of mind is being choked by "patronizing generosity" via the gifts of money. That is manipulation and dehumanizing to think we will do what people want because they have money".

Fake pastors and fraudsters capitalize on technological development and foreign aids abroad to defraud people overseas by sending fictitious videos of churches with the ulterior motive of enriching themselves with the foreign aids meant for evangelistic work in the country. This has resulted in the foreign donors refusing to give foreign aids to those that have genuine intention of carrying out evangelistic work in the country (Nkwoka, 2001). In United States of America, a secondary school student was expelled from school for preaching about 
Jesus Christ to a fellow student. Similarly, a soldier's appointment was terminated for preaching against same sex wedding in the Army Chapel. Sometime ago, the British Prime Minister, David Cameron reacted against the passing of anti-homosexual bill in Nigeria by threatening to withdraw aids from Nigeria (Nkwoka nd).

Globalization has interface with every aspect of social life creating ambiguities, variations, uncertainties and incompatibilities. It brings conflict on Christian values by making moral values relative. In fact, it has made Christian values ambiguous, uncertain and incompatible (Alli, 2006). American culture of rights and liberties have spread with the help of globalization. People now believe that there is no absolute values, rather values are relative and the choice or right of an individual is absolute. For them, there is nothing wrong with abortion, homosexuality, cohabitation before marriage and the use of genetic and reproductive technologies (Eckman, 2004). Global culture of science and technology have resulted in the wide spread of pornographic manuals, videos, fertility- pills, scourge of aids and condoms. Scientific exploits have led to artificial insemination, test tube babies, cloning and human spare parts which are negation of sacredness of human life and dignity (Catholic Secretariat of Nigeria, 1999).

\section{Recommendations}

The advanced countries should not capitalize on the economic disadvantage of the country to subjugate it to their economic hegemony.

This country needs to be careful with the way it borrows money from international financial organizations.

There is the necessity for political leaders of this country to exercise caution in their relationship with advanced countries.

The international communities are expected to respect the territorial integrity of member nations, like Nigeria.

Free movement of goods, information and heretical teachings should be checkmated by the immigration and Ministry of Information to avoid infiltration of unwholesome goods, unhealthy information and heretical teachings.

The passing of bill on anti-gay marriage by the Federal House of Assembly should be sustained by the federal government.

The proactive decision of the former primate of the church of Nigeria to severe relationship between the church of Nigeria, Provinces in Africa and the western churches that approve homosexuality should be maintained by the subsequent religious leaders of the church of Nigeria and other provinces.

It is expected that viable dioceses in church of Nigeria and other provinces that are not in support of homosexuality should assist the economic disadvantaged dioceses so that they will not be attracted to the revisionism of the west by receiving financial aids.

The Roman Catholic Church has to seek for the autonomy of the church in the country to synchronize with the political independence of the country.

International communities are expected to check the high rate of insecurity occasioned by globalization.

\section{Conclusion}

Globalization is a phenomenon that has influenced all the sectors of the society. There is no aspect of human life that is free from the influence of globalization. It is discovered that globalization has both positive and negative effects. This country just like other countries has its fair share of the influence of globalization. It has affected the country both positively and negatively. It is observed that the church which is one of the social institutions is not immune from the effects of globalization. The paradox of the relationship between the church and globalization is that the church which is one of the agents of globalization is also the victim of globalization. It is true that globalization has helped the church to spread its core values, it has at the same time negatively affected the values of the church. Therefore, it is necessary for the church to resist the negative influence of globalization on the values of the church to enable it maintain its integrity.

\section{REFERENCES}

Achunike, H.C. (2004). The Influence of Pentecostalism on Catholic Priests and Seminarians in Nigeria. Onitsha: Africana First Publishers Limited.

Adegbite, D.O. (2016). "Persecution As a Unique Mark of Christianity: A Comparative Study of The Early Church and the Modern Church" in Christianity and Persecution in the Contemporary World (eds) Asaju, D.F. et al. Abeokuta: Crowther Theological Publishers, p. 120

Agha, A.U. (2003). Religious Ethics in a Permissive Society. Enugu: SAPS.

Ajaero, U. (2018). "Capital Punishment and The Issues of Christian Morality" in Contemporary Issues for Authentic Existence (eds) Asawalam, D.O et al. Enugu: Snaap Press Limited, p.425

Akah, J. (2016). "The Resilience of Igbo Culture amidst Christianity and Westernization in Orlu Local Government Area of Imo State in Nigeria". International Journal of Theology and Reformed Tradition 
(IJTRT)' Volume 8, p.111

Alli, W.O. (2006). "The Impact of Globalization on Conflicts in Africa" in Introduction to Peace and Conflict Studies in West Africa (ed) Best, S.G. Ibadan: Spectrum Books Limited, p.336-339

Carter, C.S., Weeks, G.E. et al (1933). The Protestant Dictionary, London: Harrison Trust.

Casanova, J. (2013). "Globalization and the Growing Church". Available on https://berkleycenter.georgetown.edu.

Catholic Secretariat of Nigeria (1999). Church in Nigeria Family of God on Mission. Lagos: Catholic Secretariat of Nigeria.

Chukwuemeka, U.E. (2004). Opting for the Poor. Enugu: Snaap Press.

Cook, E.D. (1991). "Truth, Mystery and Justice: Hick and The Myth of Christian Uniqueness" in One God One Lord (eds) Clarke, A.D. and Winter, B.W. Cambridge: Tyndale House, p.188

Cross, F.L. and Livingstone, A. (1974). The Oxford Dictionary of the Christian Church. London: Oxford University Press.

Diara, B.C.D. (2010). "The Role of Christian Religion in the Evolution of Capitalism and Globalization" Nsukka Journal of Religion and Cultural Studies, Volume 3,(1), p.29

Dike, A. (2015). Church, Society and Globalization. Jos: Challenge Publications.

Dillenberger, J. (1961). Martin Luther. New York: Doubleday and Company.

Eckman, J.P. (2004). The Truth about World Views .Illinois: Goodnews Publishers.

Ehusani, G.O. (nd). A Prophetic Church. Ibadan: Kraft Books Limited.

Fraser, D.A. (2008). "Globalization” in Global Dictionary of Theology (eds) Dyrness, W.A. and Karkkainen, V. England: Inter-Varsity Press, p.336

Glendon, M.A. (nd). "Globalization and the church's New Challenges". Available on https://www.catholiceducation.org.

Griffiths, B. (2010). "The Challenge of Globalization to the Church" in Religion and Liberty. Volume 17, number 1. Available on https://action.org.

Gwamna, J.D. (2010). Religion and Politics in Nigeria. Bukuru: Africa Christian Textbooks.

Igboabuchi, B.O. and Ofojebe, W.N. (2010). Philosophy and Theories of Education (revised edition). Onitsha: Lincel Publishers.

Iluno. N. (2015). A Glosary of Ecclesiastical and liturgical Terms. Lagos: Rehoboth Publishing.

Ireoba, P.O. (2018). The Anglican Way. Nnewi: Alive unto God Printing and Publishing House.

Mbah, P. (2007). "Africa, Globalization and International Terrorism: Reflections on Contemporary Circuits of Global Capital and violence". Nigeria Journal of Humanities and Social Sciences, Volume 1. P.119-120

McGuire, M.B. (1997). Religion the Social Context (4 ${ }^{\text {th }}$ edition). London: International Thomson Publishing Company.

Ndiokwere, N.I. (1994). The African Church, Today and Tomorrow, Volume 11. Enugu: Snaap Press.

Nkwoka, A.O. (2001). The Sure Foundation. Ibadan: Scripture Union Press.

Nkwoka, A.O. (nd). "The Growing Church and Her Battles (Eph 6:10-20)" in Liberating the Church, np: Ophelia Printers, p.15-124

Nmah, P.E. (2008). Religion and Society in Africa. Enugu: Rabboni Publishers International.

Nwala, T.U. (1985). Igbo Philosophy. Ikeja: Lantern Books:

Nwankiti, A.B. (2000). The Lambeth conferences and the Growth of the Anglican Communion. Owerri: Springfield Publishers.

Obilo, E.E. (1986). The Anglicans and what They Believe. Owerri : Luton Press Limited.

Obilor, I.J. (2014). "The need for Ecumenism in A Divided Christianity: The Igbo land Example" . Journal of Religion and Society in Africa, volume 1, (2), p.11

Ofoego, C.O. (2017). Philosophy of Education: Focusing Higher Institutions. Owerri: Wilderness Voice Press.

Okafor, A.A. (2004). Poverty and Human Development in Nigeria. Nsukka: Great AP Express Publishers.

Okaneme, G. (2010). "The Socratic Maxim of the Unexamined life and its implications for Contemporary Nigerian Society". FLASH Volume 4, (1), p.107

Okere, T. (2005). Church, Theology and Society in Africa. Enugu: Fourth Dimension Publishing Company Limited.

Okoli, B.A. (2012). "African Traditional Moral Values: Path to Sustainable National Development” . Nsukka Journal of Religion and Cultural Studies, Volume 5, p.133

Omoregbe, J.. (1993). Ethics A Systematic and historical study. Ikeja: Joja Press Limited.

Oparaojiaku, C.C. (1997). The Theology of Catechism. Port Harcourt: Spiritual Life Outreach.

Osaghae, P.I. and Haaga, P.T. (2017). "A Constructive Analysis of John Dewey's Pragmatism” . International Journal of Research in Arts and Social Sciences. Volume 10, (1 \& 2). P.96

Ozumba, G.O. (2018). "The pathway to Rational Globalization through the Philosophy of Integrative Humanism" in Contemporary Issues for Authentic Existence (eds) Asawalam, D.O. et al. Enugu: Snaap 
Press, p. 150

Richardson, A. (1969). "Christian, Christianity” in A Dictionary of Christian Theology (ed) Richardson, A. London: SCM Press Limited.p.50

Stott, J.R. (1963). Basic Christianity. London: Inter-Varsity Fellowship.

Tillich, P. (1963). The Protestant Era: Chicago: University of Chicago Press.

Tillich, P. (1957). The Protestant Era Abridged. Chicago. The University of Chicago Press.

Ubani, C.C. (2016). "USA Legal Adoption of Homosexuality: A Potential threat to Orthodox Christians" in Christianity and Persecution in the Contemporary World (eds) Asaju, D.F. et al. Abeokuta: Crowther Theological Publishers, p.382

Uchechukwu, N., Elizabeth, O. et al. (2018). "Diplomacy under Political Leadership Compared to Military leadership" in Contemporary Issues for Authentic Existence (eds) Asawalam, D.O. et al. Enugu: Snaap Press Limited, p.654

Ugwuanyi, C.U. and Agwu, I.O. (2012). "Globalization: Capitalist Imperialism". International Journal of Research in Arts and Social Sciences, Volume 4, p. 80-81

Uzukwu, E. (1996). A Listening Church. Enugu: Snaap Press.

Wach, J. (1958). The Comparative Study of Religions. New York: Columbia University Press.

Dr Friday Ogbuehi is a lecturer at the Department of Religious Studies, Crowther Graduate Theological Seminary, Abeokuta, Ogun State, Nigeria where he teaches graduate students. He specializes in Sociology of Religion. Dr Ogbuehi is also the Registrar of the Seminary. 